\title{
Mitotane alters mitochondrial respiratory chain activity by inducing cytochrome $c$ oxidase defect in human adrenocortical cells
}

\author{
Ségolène Hescot ${ }^{1,2}$, Abdelhamid Slama ${ }^{3}$, Anne Lombès ${ }^{4}$, Angelo Paci ${ }^{5}$, Hervé Remy ${ }^{5}$, \\ Sophie Leboulleux ${ }^{6}$, Rita Chadarevian ${ }^{7}$, Séverine Trabado, ${ }^{1,2,8}$, Larbi Amazit ${ }^{1,2}$, \\ Jacques Young ${ }^{1,2,9}$, Eric Baudin ${ }^{1,2,5, *}$ and Marc Lombès ${ }^{1,2,9, *}$ \\ ${ }^{1}$ INSERM U693, Fac Med Paris Sud, Rue Gabriel Péri, Le Kremlin-Bicêtre F-94276, France ${ }^{2}$ UMR-S693, Univ Paris-Sud, \\ Fac Med Paris-Sud, Le Kremlin Bicêtre F-94276, France ${ }^{3}$ Assistance Publique-Hôpitaux de Paris, Service de Biochimie, \\ Hôpital de Bicêtre, Le Kremlin Bicêtre F-94275, France ${ }^{4}$ INSERM UMRS 1016, Institut Cochin, Paris F-75014, France \\ ${ }^{5}$ Service Interdépartemental de Pharmacologie et d'Analyse du Médicament, Institut Gustave Roussy, Villejuif \\ F-94805, France ${ }^{6}$ Oncologie Endocrinienne, Institut Gustave Roussy, Villejuif F-94805, France ${ }^{7}$ HRA Pharma, Paris \\ F-75003 France ${ }^{8}$ Assistance Publique-Hôpitaux de Paris, Service de Génétique Moléculaire, Pharmacogénétique \\ et Hormonologie, Hôpital de Bicêtre, Le Kremlin Bicêtre F-94275, France ${ }^{9}$ Assistance Publique-Hôpitaux de Paris, \\ Service d'Endocrinologie et des Maladies de la Reproduction, Hôpital de Bicêtre, Le Kremlin Bicêtre F-94275, France \\ *(E Baudin and M Lombès contributed equally to this work)
}

Correspondence should be addressed to $M$ Lombès Email marc.lombes@u-psud.fr

\begin{abstract}
Mitotane, 1,1-dichloro-2-(o-chlorophenyl)-2-(p-chlorophenyl)ethane is the most effective medical therapy for adrenocortical carcinoma, but its molecular mechanism of action remains poorly understood. Although mitotane is known to have mitochondrial (mt) effects, a direct link to $\mathrm{mt}$ dysfunction has never been established. We examined the functional consequences of mitotane exposure on proliferation, steroidogenesis, and $\mathrm{mt}$ respiratory chain, biogenesis and morphology, in two human adrenocortical cell lines, the steroid-secreting H295R line and the non-secreting SW13 line. Mitotane inhibited cell proliferation in a dose- and a time-dependent manner. At the concentration of $50 \mu \mathrm{M}(14 \mathrm{mg} / \mathrm{l})$, which corresponds to the threshold for therapeutic efficacy, mitotane drastically reduced cortisol and 17-hydroxyprogesterone secretions by $70 \%$. This was accompanied by significant decreases in the expression of genes encoding $\mathrm{mt}$ proteins involved in steroidogenesis (STAR, CYP11B1, and CYP11B2). In both H295R and SW13 cells, $50 \mu \mathrm{M}$ mitotane significantly inhibited (50\%) the maximum velocity of the activity of the respiratory chain complex IV (cytochrome c oxidase (COX)). This effect was associated with a drastic reduction in steady-state levels of the whole COX complex as revealed by blue native PAGE and reduced mRNA expression of both mtDNA-encoded COX2 (MT-CO2) and nuclear DNA-encoded COX4 (COX4I1) subunits. In contrast, the activity and expression of respiratory chain complexes II and III were unaffected by mitotane treatment. Lastly, mitotane exposure enhanced $\mathrm{mt}$ biogenesis (increase in mtDNA content and PGC1 $\alpha$ (PPARGC1A) expression) and triggered fragmentation of the $m t$ network. Altogether, our results provide first evidence that mitotane induced a mt respiratory chain defect in human adrenocortical cells.
\end{abstract}

\author{
Key Words \\ - adrenocortical carcinoma \\ - mitotane \\ - o, $p^{\prime}$-DDD \\ - mitochondria \\ - cytochrome c oxidase
}

Endocrine-Related Cancer (2013) 20, 371-381 (c) 2013 Society for Endocrinology Printed in Great Britain
Published by Bioscientifica Ltd 


\section{Introduction}

Adrenocortical carcinoma (ACC) is a rare disease affecting two patients per million people per year, representing $<0.1 \%$ of all cancer cases. ACC prognosis is poor with $<15 \%$ of patients surviving 5 years or more once metastases are diagnosed (Icard et al. 2001, Assie et al. 2007, Fassnacht \& Allolio 2009, Lughezzani et al. 2010).

Mitotane, 1,1-dichloro-2-(o-chlorophenyl)-2-( $p$-chlorophenyl)ethane $\left(o, p^{\prime}\right.$-DDD), is a synthetic derivative of an insecticide. It acts selectively on the adrenal cortex where it has a cytotoxic effect and impairs steroidogenesis (Bergenstal \& Dao 1953). Mitotane is a part of the reference treatment of advanced ACC (Berruti 2012, Fassnacht et al. 2012). Indeed, it remains the single most effective drug, inducing a partial response in up to one third of the treated patients (Baudin et al. 2011). Several retrospective studies have shown that plasma mitotane levels above $14 \mathrm{mg} / \mathrm{l}$ are associated with a higher partial response rate and improve overall survival (Haak et al. 1994, Baudin et al. 2001, Malandrino et al. 2010, Wangberg et al. 2010, Hermsen et al. 2011). The current recommendation to achieve optimal benefit over risk ratio in patients with unresectable ACC is to maintain plasma mitotane levels between 14 and $20 \mathrm{mg} / \mathrm{l}$ (Berruti 2012).

Mitotane's molecular mechanisms of action remain largely unknown, although mitochondrial (mt) effects have been reported. Kaminsky et al. (1962) observed swollen mitochondria in the adrenal cortex of mitotanetreated dogs by electron microscopy. Subsequently, Martz $\&$ Straw (1977) suggested that metabolic transformation of $o, p^{\prime}$-DDD into the active metabolite $o, p^{\prime}$-DDA occurs in mitochondria and is catalyzed by an unknown cytochrome P450. Mitotane metabolism seems to involve two successive reactions of $\beta$-hydroxylation and dehydrochlorination, leading to production of free radicals that could potentially result in apoptosis (Cai et al. 1995). Critical steps of mitotane's inhibitory effects on steroidogenesis may occur in mitochondria possibly involving CYP11A1, a mt enzyme that catalyzes the transformation of cholesterol to pregnenolone (Cai et al. 1997). Elevated levels of 11-deoxycortisol and 11-deoxycorticosterone in mitotane-treated patients suggest that mitotane may affect CYP11B1, which is responsible for cortisol synthesis (Asp et al. 2012). More recently, Stigliano et al. (2008) showed by proteomic analysis of H295R cells that expression of proteins involved in stress response, energy metabolism, and tumorigenesis was greatly altered by mitotane exposure. Interestingly, some of these regulated proteins were $\mathrm{mt}$ components, even though a direct impact on their synthesis and/or stability has not been clearly demonstrated. The functional consequences of mitotane on respiratory chain expression and activity have not yet been examined. The respiratory chain consists of four multienzymatic complexes located in the mt inner membrane. Together with the ATP synthase complex, it performs an essential $\mathrm{mt}$ function, generating the vast majority of cellular ATP synthesis, while reducing molecular oxygen into water. It is a major source of free radicals in most cells and its function is tightly linked to apoptosis balance. The respiratory chain has been shown to be the target of several pharmacological compounds including non-steroidal anti-inflammatory drugs, antiretrovirals, and chemotherapy agents (Viengchareun et al. 2007, Fedeles et al. 2011, Scatena 2012).

The aim of this study was to evaluate the functional consequences of mitotane exposure on $\mathrm{mt}$ oxidative phosphorylation (OXPHOS) in human adrenocortical steroid-secreting H295R and non-secreting SW13 cells, both derived from human ACC. We used complementary experimental approaches including spectrophotometric assays, western blot, quantitative PCR, and mt morphological analysis to explore how mitotane affects mediators of steroidogenesis and respiratory chain activity.

\section{Materials and methods}

\section{Cell culture and treatment}

H295R and SW13 cells were cultured in DMEM/HAM'S F-12 (PAA, Les Mureaux, France) supplemented with 20 mM HEPES (Invitrogen, Life Technologies), antibiotics (penicillin $100 \mathrm{IU} / \mathrm{ml}$ and streptomycin $100 \mu \mathrm{g} / \mathrm{ml}$ ), and $2 \mathrm{mM}$ glutamine. The medium for H295R cell culture was enriched with $10 \%$ fetal bovine serum and a mixture of insulin/transferrin/selenium. Both cell lines (from passages 2-15) were cultured at $37^{\circ} \mathrm{C}$ in a humidified incubator with $5 \% \mathrm{CO}_{2}$. Mitotane (supplied by HRA Pharma, Paris, France) dissolved in DMSO was added to cell cultures at final concentrations of $10-100 \mu \mathrm{M}$; the therapeutic plasma mitotane level is $50 \mu \mathrm{M}$ (approximately $14 \mathrm{mg} / \mathrm{l})$.

\section{Cell proliferation analysis}

Cell proliferation was studied in Celltiter 96 assays (Promega) according to the manufacturer's recommendations. Cells were cultured in 96-well plates and treated

Published by Bioscientifica Ltd. 
with $10-100 \mu \mathrm{M}$ mitotane for 24,48 , or $72 \mathrm{~h}$. Absorbance was measured by photometry (Viktor, Perkin Elmer, Courtaboeuf, France) $1 \mathrm{~h}$ after addition of $20 \mu \mathrm{l}$ Celltiter solution per well.

\section{Cortisol and 17-hydroxyprogesterone secretion}

The cortisol and 17-hydroxyprogesterone (17-OHprogesterone) concentrations in H295R culture supernatants were determined by radioimmunometric assays using polyclonal antibodies (anti-cortisol: Orion Diagnostica, Spectria, Espoo, Finland; anti-17-OH-progesterone: MP Biomedical, Solon, OH, USA). The intra- and interassay coefficients of variation of the cortisol were respectively 4.5 and $5.5 \%$ at $22 \mu \mathrm{g} / \mathrm{l}$, and 4.2 and $4.3 \%$ at $269 \mu \mathrm{g} / \mathrm{l}$, with a detection limit of $5 \mu \mathrm{g} / \mathrm{l}$ while those of the $17-\mathrm{OH}-$ progesterone assay were 7.8 and $12 \%$ at $0.92 \mathrm{ng} / \mathrm{ml}$, and 8.3 and $9.8 \%$ at $4.3 \mathrm{ng} / \mathrm{ml}$ with a detection limit of $0.02 \mathrm{ng} / \mathrm{ml}$.

\section{Reverse transcriptase-PCR and quantitative real-time PCR}

Total RNA was extracted from tissues or cells with the RNeasy Kit (Qiagen) according to the manufacturer's recommendations. RNA was thereafter processed for reverse transcriptase-PCR (RT-PCR) as described previously (Martinerie et al. 2011). Quantitative real-time PCR (qRT-PCR) was performed using the Fast SYBR Green Master Mix (ABI, Applied Biosystems) and carried out on a StepOnePlus Real-Time PCR System (Applied Biosystems) as described previously (Martinerie et al. 2011). Standards and samples were amplified in duplicate and analyzed from three independent experiments. The internal control for data normalization was the ribosomal $18 \mathrm{~S}$ rRNA. The relative expression of each gene is expressed as the ratio of attomoles of the specific gene to femtomoles of $18 \mathrm{~S}$ rRNA. The primer sequences of the genes analyzed by qRT-PCR are shown in the Supplementary Table 1, see section on supplementary data given at the end of this article.

\section{mtDNA quantification}

mtDNA quantification was performed on total DNA extracted from tissues or cells using standard techniques. DNA was quantified by qPCR using the cytochrome $c$ oxidase 2 (COX2 (MT-CO2)) gene on the mtDNA as a target gene as described previously (Viengchareun et al. 2007). Results were expressed as relative expression of COX2 normalized with the nuclear 185 gene.

\section{Respiratory chain analysis}

Respiratory chain activities were measured using spectrophotometric assays. H295R and SW13 cells were treated with mitotane or vehicle (DMSO) alone for various periods, 24, 48 , or $72 \mathrm{~h}$, and the activity of four mt respiratory complexes - complex I (NADH-ubiquinone oxidoreductase), complex II (succinate-ubiquinone oxidoreductase), complex III (ubiquinone-cytochrome $c$ oxidoreductase), and complex IV (COX) - were measured in a Cary 50 Spectrophotometer (Rustin et al. 1994). Assays of complexes II, III, and IV were performed on cell homogenates, and their activities normalized to citrate synthase activity, as an index of mt mass. Complex I assays were performed on purified $\mathrm{mt}$ fractions and prepared from permeabilized cells as described previously (Chretien et al. 2003).

\section{BN-PAGE analysis}

Mitochondria and OXPHOS complexes were isolated from cultured cells using $2 \%(\mathrm{~W} / \mathrm{V})$ digitonin and analyzed as described (Nijtmans et al. 2002a,b). Fifteen micrograms of solubilized OXPHOS proteins were loaded on a $4-16 \%$ gradient acrylamide non-denaturing gel (Invitrogen). After electrophoresis, proteins were transferred to a PVDF membrane. Immunoblotting was performed with MABs (Mitosciences, Mundolsheim, France) raised against the complex I subunit GRIM19, the $70 \mathrm{kDa}$ complex II subunit, the complex III subunit core2, and the complex IV subunit COX1. Peroxidase-conjugated anti-mouse IgG secondary antibodies were added and the signal was generated using ECL (Pierce, Rockford, IL, USA). Membranes were scanned using the Odyssey infrared imaging system and images were processed with the Image Studio Software (LI-COR Biosciences, Lincoln, NE, USA).

\section{mt morphology}

Cells were seeded at subconfluence on a glass coverslip and incubated for 24-48 h in the presence or absence of $50 \mu \mathrm{M}$ mitotane, briefly rinsed with warm PBS, and then fixed in 3\% paraformaldehyde in PBS. Mitochondria were labeled with antibodies against COX2 subunit as described (Agier et al. 2012).

\section{Statistical analysis}

Results are expressed as means \pm s.E.M. of $n$ independent replicates performed in the same experiment or from $n$ separated experiments. Differences between groups were

Published by Bioscientifica Ltd 
analyzed using nonparametric Kruskal-Wallis ANOVA followed by Dunn's multiple comparison test or nonparametric Mann-Whitney $U$ test as appropriate. The significance level was $P<0.05$.

\section{Results}

Mitotane treatment reduces human adrenocortical H295R and SW13 cell proliferation

Proliferation index was calculated using the colorimetric solution Celltiter 96. Exposure to mitotane for $48 \mathrm{~h}$ inhibited the proliferation of H295R and SW13 cells in a dose-dependent manner, $100 \mu \mathrm{M} o, p^{\prime}$-DDD significantly reducing the proliferation rate of $\mathrm{H} 295 \mathrm{R}$ by $45 \%$ and that of SW13 cells by $30 \%$ (Fig. 1A and B). The anti-proliferative effect of mitotane was also time dependent, $100 \mu \mathrm{M}$ mitotane inhibiting the proliferation of H295R cells by $18 \%$ after $24 \mathrm{~h}$ and by $70 \%$ after $72 \mathrm{~h}$. Subsequent experiments were performed using $50 \mu \mathrm{M}$ mitotane to minimize the drug's potential cytotoxic effects.

\section{Effect of mitotane on steroidogenesis in H295R cells}

To confirm the ability of mitotane to inhibit hormone secretion, we measured several steroid hormone concentrations in the culture supernatant of H295R cells. Exposure to $50 \mu \mathrm{M}$ mitotane for $48 \mathrm{~h}$ significantly reduced the secretion of both cortisol and 17-OH-progesterone about $80 \%$ by H295R cells (Fig. 1C). Other steroid hormones such as aldosterone were undetectable in culture supernatants under these experimental conditions.

To address the mechanisms underlying this decreased steroid secretion, we analyzed the expression of genes that encode $\mathrm{mt}$ effectors of steroidogenesis by qRT-PCR. Mitotane significantly decreased the expression of such genes: STAR, which encodes the STAR that transports cholesterol into mitochondria, the first rate-limiting step for the intra-mt steroidogenic pathway (80\% inhibition after 48 h; Fig. 2A); cholesterol desmolase (CYP11A (CYP11A1)), 3ß-hydroxysteroid dehydrogenase (HSD3B2); 11ß-hydroxylase (CYP11B1), which catalyzes 11-deoxycorticosterone and 11-deoxycortisol transformation into corticosterone and cortisol respectively (75\% inhibition; Fig. 2B); and aldosterone synthase (CYP11B2), the last intra-mt enzymatic step in aldosterone synthesis (97\%, inhibition; Fig. 2C). The mitotane-induced inhibition of steroid secretion observed in H295R cells therefore appeared to be due to decreased expression of the steroidogenic enzymes.
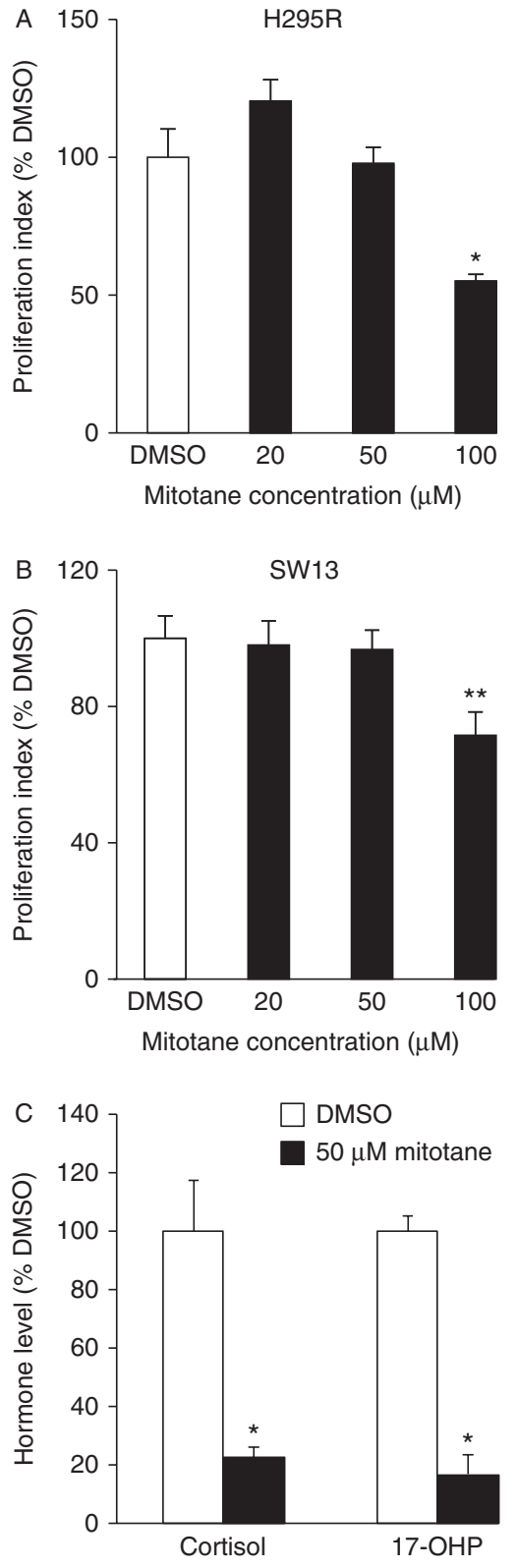

Figure 1

Dose-dependent inhibition of the proliferation index of human adrenocortical H295R (A) and SW13 (B) cells in response to increasing concentrations of mitotane $(0-100 \mu \mathrm{M})$ after $48 \mathrm{~h}$, as determined by Celltiter assay (See Materials and methods section). Results are expressed as the mean percentage \pm s.E.M. of 12 independent determinations of the expression measured in untreated cells, arbitrarily set at $100 \%$. ${ }^{*} P<0.05$ and $* * P<0.01$, Mann-Whitney $U$ test. Proliferation was affected in a dose-dependant manner in both cell lines. Inhibition of cortisol and 17-hydroxyprogesterone secretions by the steroid-secreting H295R cells (C). Cells were cultured with $50 \mu \mathrm{M}$ mitotane for $48 \mathrm{~h}$ and the steroid concentrations were measured in the cell supernatants by radioimmunometric assays. Results are means \pm s.E.M. of four independent determinations and are expressed as percentage of secretion under basal conditions (mean cortisol and 17-OHP secretions were 157 and $358 \mathrm{ng} / 48 \mathrm{~h}$ per $\mathrm{mg}$ protein per well respectively). Steroid hormone secretion was significantly inhibited by $80 \%$ after mitotane exposure.

Published by Bioscientifica Ltd. 

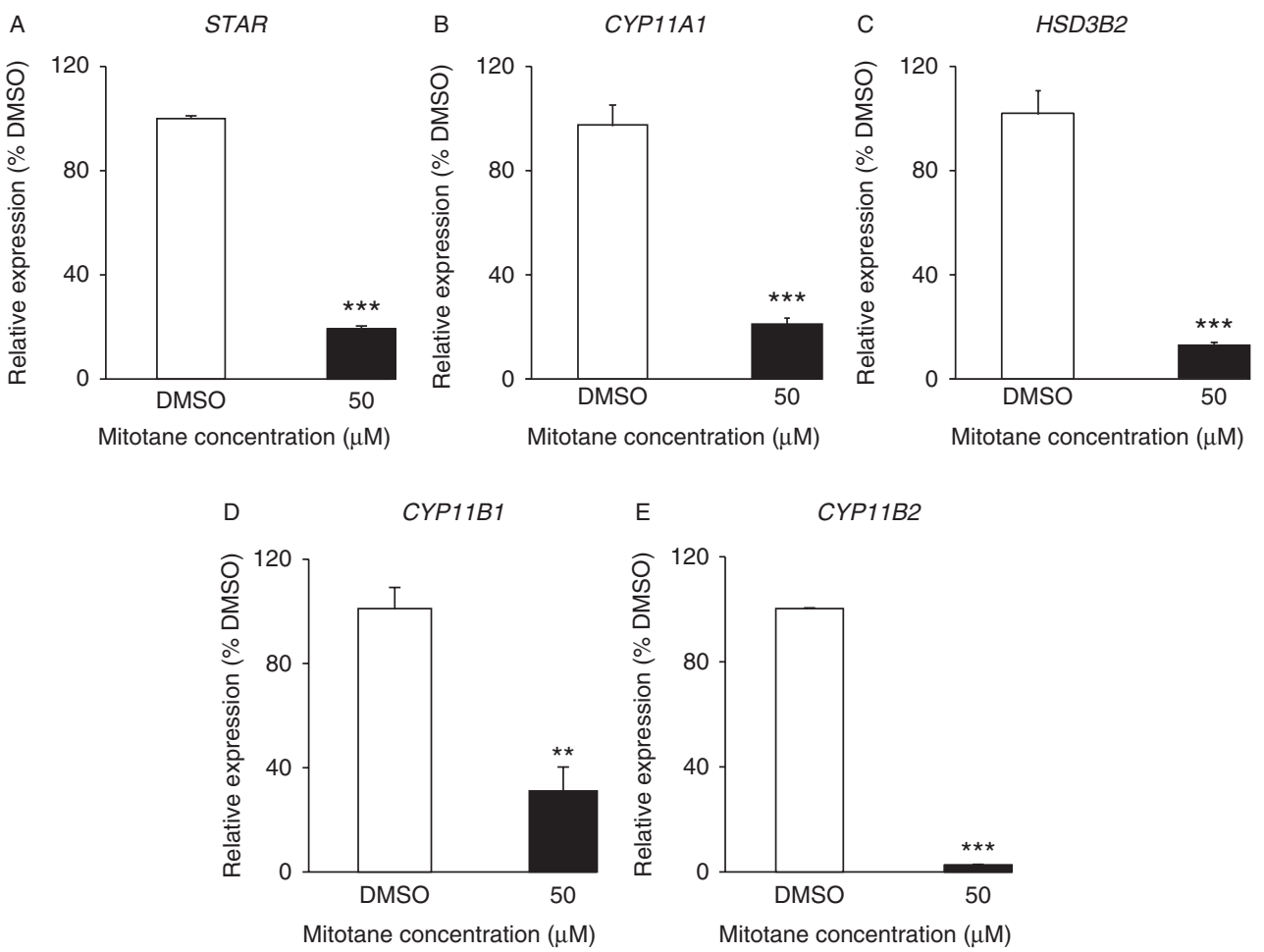

Mitotane concentration $(\mu \mathrm{M})$

Figure 2

Expression of genes encoding mitochondrial and cytoplasmic proteins involved in steroidogenesis. H295R cells were treated with $50 \mu \mathrm{M}$ mitotane for $48 \mathrm{~h}$. Relative mRNA expression of (A) STAR, (B) CYP11A, (C) HSD3B2, (D) CYP11B1, and (E) CYP11B2 was determined using qRT-PCR. Results are means \pm s.E.M. of four different experiments performed in duplicate and are expressed as the percentage of the relative expression in DMSO-treated cells, arbitrarily set at $100 \%$. Mitotane drastically inhibits gene expression. $* * P<0.01$ and $* * * P<0.001$, Mann-Whitney $U$ test.

\section{Effect of mitotane on the respiratory chain}

The impact of mitotane on respiratory chain activity was evaluated by spectrophotometric assays of the activities of the four mt respiratory complexes in H295R and SW13 cells treated with vehicle (DMSO) or $50 \mu \mathrm{M}$ mitotane during $48 \mathrm{~h}$ (Table 1). Citrate synthase activity, belonging to the mt citric acid cycle, was used as an index of the $\mathrm{mt}$ mass. Its activity was very high in H295R cells (299 \pm $22 \mathrm{nmol} / \mathrm{min}$ per $\mathrm{mg}$ protein; $n=12$ ) but lower in SW13 cells $(159 \pm 11 \mathrm{nmol} / \mathrm{min}$ per $\mathrm{mg}$ protein; $n=8)$, suggesting that H295R cells have a greater mt population than SW13 cells consistent with their important steroidogenic capacity. However, citrate synthase activity was not affected by mitotane exposure $(260 \pm 31 \mathrm{nmol} / \mathrm{min}$ per $\mathrm{mg}$ protein in H295R and $135 \pm 7 \mathrm{nmol} / \mathrm{min}$ per $\mathrm{mg}$ protein in SW13 cells).

Both H295R and SW13 mitotane-treated cells exhibited a significant COX (or complex IV) defect of $\sim 50 \%$ after $48 \mathrm{~h}$ while complex II (succinate-ubiquinone oxidoreductase) appeared unaffected (Table 1). Complex III (ubiquinol-cytochrome $c$ oxidoreductase) activity remained unchanged in H295R cells and was slightly reduced in SW13 cells after mitotane treatment (Table 1), but this decrease was not confirmed after normalization to citrate synthase activity (Table 1). Complex I (NADHubiquinone oxidoreductase) activity can only be reliably

Table 1 Mitochondrial respiratory activities.

\begin{tabular}{|c|c|c|c|c|}
\hline \multirow[b]{2}{*}{ Conditions } & \multicolumn{2}{|c|}{ H295R cells } & \multicolumn{2}{|c|}{ SW13 cells } \\
\hline & Vehicle & $\begin{array}{l}50 \mu \mathrm{M} \\
\text { mitotane }\end{array}$ & Vehicle & $\begin{array}{l}50 \mu \mathrm{M} \\
\text { mitotane }\end{array}$ \\
\hline Citrate synthase & $299 \pm 22$ & $260 \pm 31$ & $159 \pm 11$ & $135 \pm 7$ \\
\hline Complex I & $8.3 \pm 0.7$ & $3.6 \pm 1.1 *$ & $1 \overline{4} .4$ & $\overline{7.5}$ \\
\hline Complex II & $55 \pm 8$ & $43 \pm 9$ & $37 \pm 3$ & $32 \pm 1$ \\
\hline Complex III & $95 \pm 14$ & $86 \pm 26$ & $89 \pm 6$ & $55 \pm 10 *$ \\
\hline Complex IV & $276 \pm 15$ & $153 \pm 19^{\dagger}$ & $283 \pm 53$ & $127 \pm 37^{\dagger}$ \\
\hline $\mathrm{ClI} / \mathrm{CS}$ & $0.28 \pm 0.03$ & $0.21 \pm 0.03$ & $0.26 \pm 0.02$ & $0.30 \pm 0.04$ \\
\hline CIII/CS & $0.29 \pm 0.03$ & $0.36 \pm 0.07$ & $0.68 \pm 0.07$ & $0.68 \pm 0.10$ \\
\hline CIV/CS & $1.05 \pm 0.08$ & $0.52 \pm 0.02^{\ddagger}$ & $0.78 \pm 0.08$ & $0.56 \pm 0.01$ * \\
\hline
\end{tabular}

Enzymatic activities were measured in cell homogenates with the exception of complex I, which was measured on purified mitochondrial fractions; values are mean \pm s.E.M. of 6-12 independent experiments, expressed as $\mathrm{nmol} / \mathrm{min}$ per mg protein. Ratio between complex II or complex III or complex IV:citrate synthase (CS) activities is also presented. $* P<0.05$, ${ }^{\dagger} P<0.01$, and ${ }^{\ddagger} P<0.001$ with nonparametric Mann-Whitney $U$ test. http://erc.endocrinology-journals.org DOI: $10.1530 /$ ERC-12-0368
(C) 2013 Society for Endocrinology Printed in Great Britain 


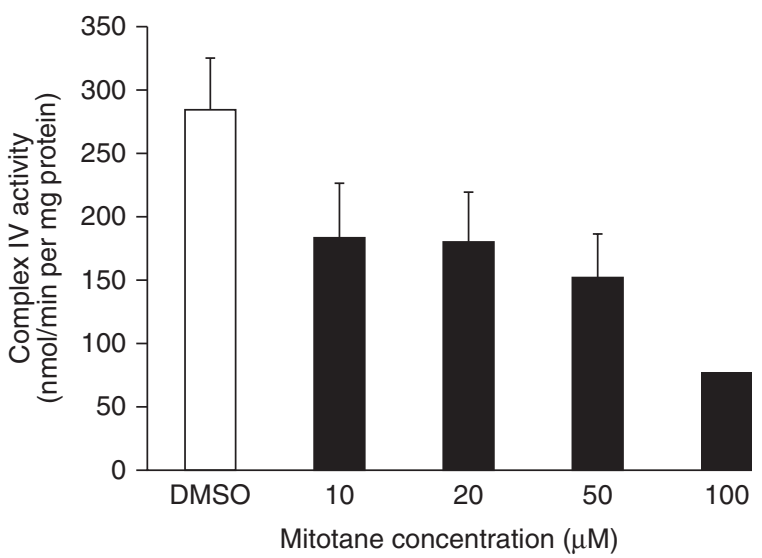

Figure 3

Dose-dependent inhibition of cytochrome c oxidase (complex IV, COX) activity in H295R cells by mitotane. H295R cells were treated for $48 \mathrm{~h}$ with increasing concentrations of mitotane $(0-100 \mu \mathrm{M})$ and the COX activity was measured by spectrophotometry as described in the Materials and methods section. Results are expressed as $\mathrm{nmol} / \mathrm{min}$ per $\mathrm{mg}$ protein. Each point represents the mean of three to six independent determinations. Mitotane inhibits complex IV activity in a concentration-dependant manner with a calculated $\mathrm{IC}_{50}$ at $58 \mu \mathrm{M}$.

measured on purified $\mathrm{mt}$ fractions due to the presence of numerous non-mt NADH oxidase activities in cell homogenates but its activity was greatly decreased after exposure to mitotane in both human adrenocortical cell lines after exposure to mitotane (Table 1). Altogether, our results demonstrate that mitotane selectively inhibits some but not all respiratory chain complexes.

The effect of mitotane on complex IV was concentration dependent, as shown in Fig. 3, with an $\mathrm{IC}_{50}$ calculated at $\sim 67 \mu \mathrm{M}$ mitotane (linear regression test; $\left.y=92.862-0.583 x, r^{2}=0.97\right)$. This mitotane concentration corresponds to the therapeutic plasma threshold predictive of efficacy in clinical practice (Haak et al. 1994, Baudin et al. 2001).

To examine whether $o, p^{\prime}$-DDD might directly affect the enzymatic activity of complex IV, we measured COX activity on cell homogenates incubated with increasing concentrations of mitotane. Under these conditions, we demonstrated that mitotane dose dependently decreased complex IV activity with an $\mathrm{IC}_{50}$ of $\sim 133 \mu \mathrm{M}$ (linear regression test; $y=100.2-0.3749 x, r^{2}=0.96$; Fig. 4). This $\mathrm{IC}_{50}$ in the cell homogenate system is twice as high as the $\mathrm{IC}_{50}$ observed when whole cells were treated for $48 \mathrm{~h}$, indicating that mitotane exerts both direct and indirect inhibitory effects on COX activity. Our results strongly suggested that mitotane inhibits enzymatic activity directly but presumably inhibits the expression of the enzyme. We therefore studied the expression of COX at both the mRNA and protein levels. The COX complex consists of 13 subunits, three of which, including COX2, are encoded by the $\mathrm{mt}$ genome while the remaining ten subunits, including COX4 (COX4I1), are encoded by nuclear genes. We observed that the steady-state levels of mt and nuclear DNA-encoded COX2 and COX4 transcripts in both H295R and SW13 cells were drastically decreased (by 70\%) in H295R cells after exposure to $50 \mu \mathrm{M}$ mitotane for $48 \mathrm{~h}$ (Fig. 5A and B). Similar results were obtained in SW13 cells (data not shown).

We analyzed the whole respiratory chain complexes by blue native PAGE (BN-PAGE). Immunoblotting with antibodies directed against a component of each $\mathrm{mt}$ complexes revealed that mitotane exposure for $48 \mathrm{~h}$ induced a $45-70 \%$ decrease in the steady-state expression of complex IV and complex I proteins while the abundance of complexes II and III appeared unchanged (Fig. 5C and $D$ ). These data were fully consistent with the decreased enzymatic activities described earlier (Table 1). Altogether, our results demonstrate that mitotane has deleterious consequences by acting at the mRNA and protein level to impair respiratory chain expression and function.

To evaluate the possibility that mitotane has direct toxic effects on the mtDNA, we quantified mtDNA by qPCR. As illustrated in Fig. 6A, the mt:nuclear DNA ratio was unaffected by exposure of low or moderate doses of

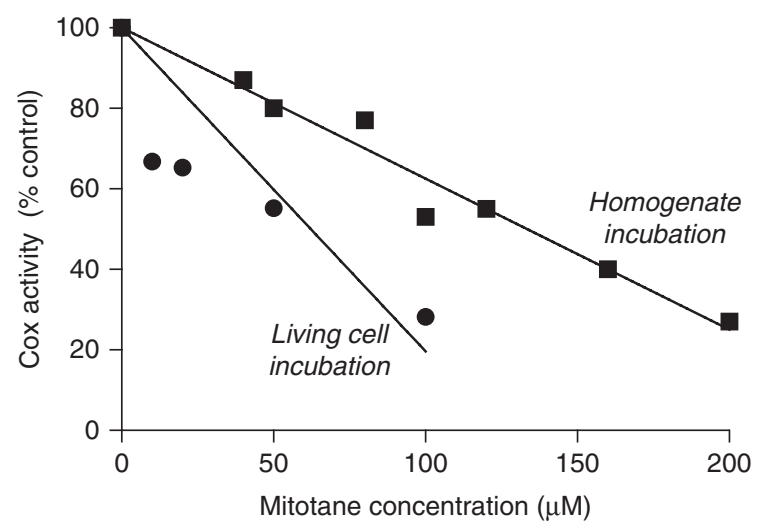

Figure 4

Dose-dependent inhibition of cytochrome c oxidase (COX) activity by mitotane. COX activity was measured by spectrophotometry in cell homogenates of H295R cells incubated with increasing concentrations of mitotane $(0-100 \mu \mathrm{M})$ for $48 \mathrm{~h}$ (black circles, living cell incubation) or in cell homogenates simultaneously exposed to increasing concentrations of mitotane (0-200 $\mu \mathrm{M})$ immediately added before the enzymatic assay (black squares, homogenate incubation). Each experiment was repeated two to six times. Results are expressed as the percentage of control COX activity measured in the absence of mitotane arbitrary set at $100 \%$. Mitotane directly inhibits complex IV activity with an $\mathrm{IC}_{50}$ at $133 \mu \mathrm{M}$ (homogenate incubation), while the $\mathrm{IC}_{50}$ of mitotane was calculated at $67 \mu \mathrm{M}$ for the inhibitory effects on treated cells (living cell incubation). 
mitotane for $48 \mathrm{~h}$. However, this ratio increased significantly after treatment with $100 \mu \mathrm{M}$ mitotane and with longer exposure times (e.g. $50 \mu \mathrm{M}$ mitotane for $72 \mathrm{~h}$ ), suggesting the presence of a compensatory response of $\mathrm{mt}$ biogenesis (Fig. 6B). To further explore this

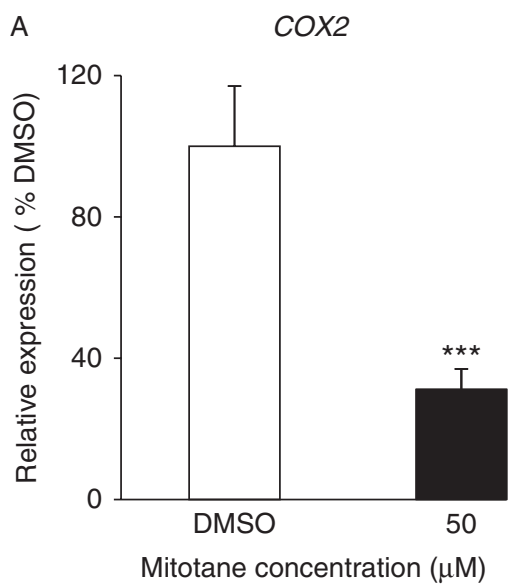

C

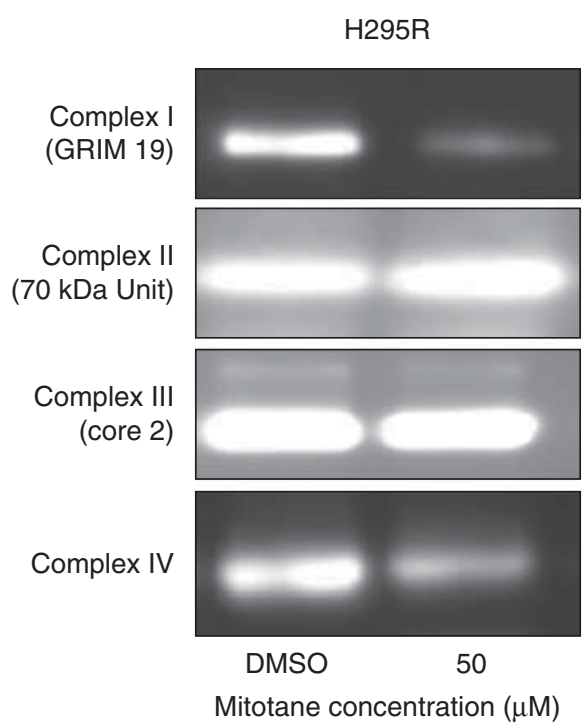

hypothesis, we quantified the expression of peroxisome proliferator-activated receptor gamma coactivator $1 \alpha$ (PGC1 $\alpha$ (PPARGC1A)), a transcriptional coactivator considered a key regulator of $\mathrm{mt}$ biogenesis. $P G C 1 \alpha$ mRNA expression was slightly but significantly induced

B
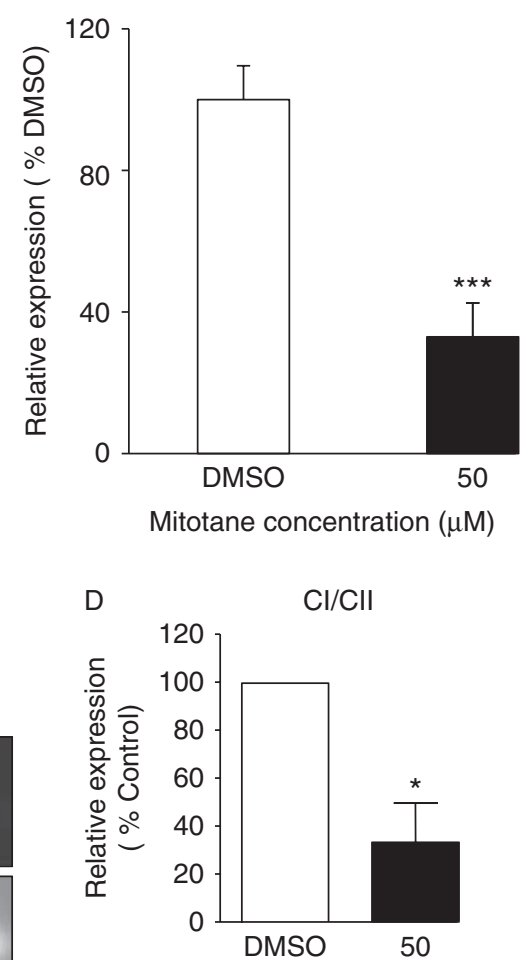

Mitotane concentration $(\mu \mathrm{M})$

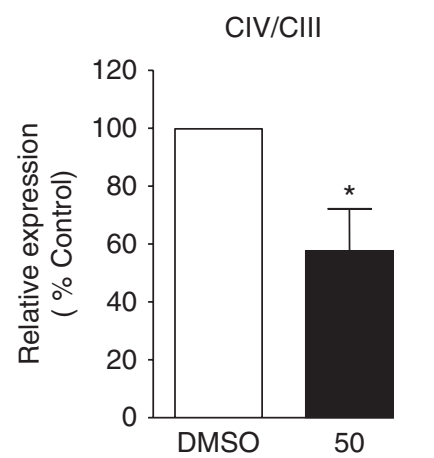

Mitotane concentration $(\mu \mathrm{M})$

\section{Figure 5}

Inhibition of the expression of the respiratory chain genes and proteins by mitotane. The steady-state levels of mRNA encoding for the mitochondrial DNAencoded COX2 (A) and the nuclear DNA-encoded COX4 (B) were measured by RT-qPCR. The expression of both COX2 and COX4 transcripts was drastically reduced after exposure to $50 \mu \mathrm{M}$ mitotane for $48 \mathrm{~h}$. Results are expressed as the mean percentage \pm s.E.M. of four independent determinations performed in duplicate of the expression measured in untreated cells, arbitrarily set at $100 \%$. ${ }^{*}<0.05$ and $* * * P<0.001$, Mann-Whitney $U$ test. Steady-state levels of respiratory chain whole complexes were analyzed by BN-PAGE followed by western blot with anti-GRIM 19 (a subunit of complex I), anti-70 kDa (a subunit of complex II), anti-core2 (a subunit of complex III), and anti-COX1 (a subunit of complex IV) (C). Band intensities were quantified by ImageJ Software revealing that mitotane reduced the steady state of both the complex I and the complex IV and were reduced by $45-70 \%$ but had no effect on complex II or complex III expression (D). Results are expressed as the mean percentage \pm s.E.M. of four independent determinations of the expression measured in untreated cells, arbitrarily set at $100 \%$. ${ }^{\star} P<0.05$, Mann-Whitney $U$ test. 

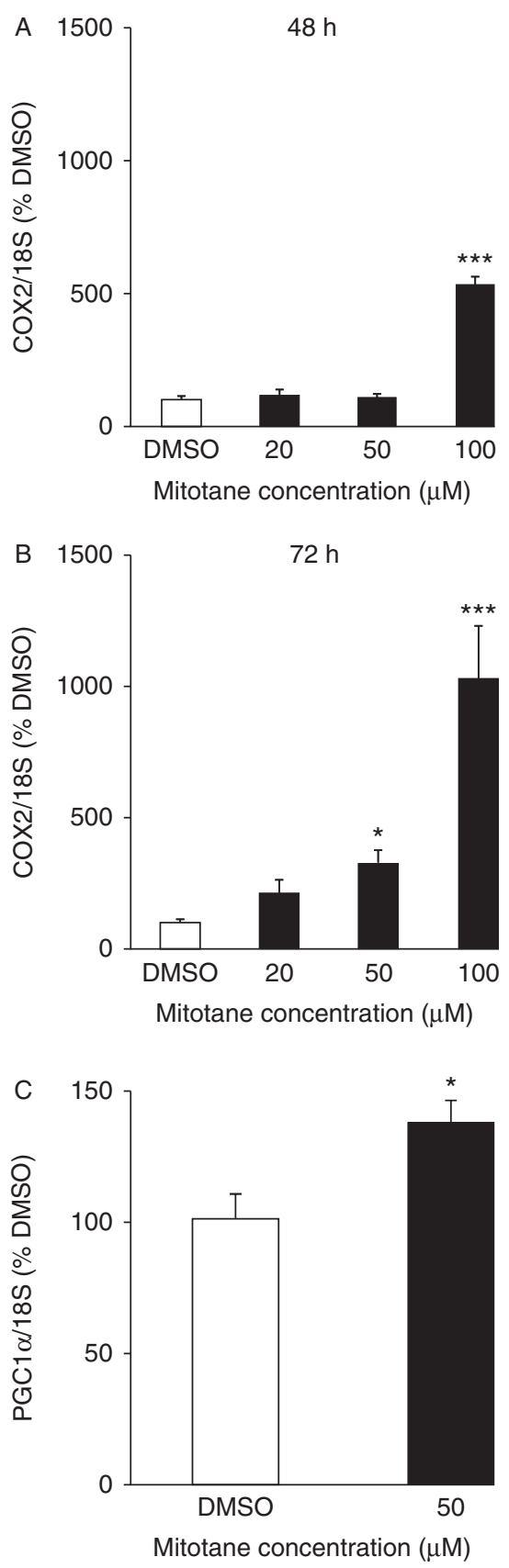

\section{Figure 6}

Stimulation of mitochondrial biogenesis by mitotane. Mitochondrial DNA was quantified by qPCR in H295R cells treated for $48 \mathrm{~h}$ (A) or $72 \mathrm{~h}$ (B) with increasing concentrations of mitotane. Higher mitotane concentrations $(100 \mu \mathrm{M})$ and longer time exposure $(72 \mathrm{~h})$ increased mitochondrial:nuclear DNA ratio. Increased expression of peroxisome proliferator-activated receptor gamma coactivator $1 \alpha(P G C 1 \alpha)$ in H295R cells was treated with $50 \mu \mathrm{M}$ mitotane for $48 \mathrm{~h}$ (C). Results are expressed as the mean percentage \pm s.E.M. of four independent determinations performed in duplicate of the expression measured in untreated cells, arbitrarily set at $100 \%$. ${ }^{*} P<0.05$ and ${ }^{*} * P<0.001$, Mann-Whitney $U$ test. by $50 \mu \mathrm{M}$ mitotane treatment for $48 \mathrm{~h}$, suggesting activation of transcriptional response (Fig. 6C). Furthermore, no mtDNA mutations or deletions were found by sequencing mtDNA from mitotane-treated cells.

\section{Effect of mitotane on mt morphology}

Finally, to get an integrated evaluation of the mitotaneinduced mt respiratory chain defect, we analyzed the $\mathrm{mt}$ morphology by immunocytochemistry using an antibody against COX2. Treatment with $50 \mu \mathrm{M}$ mitotane induced drastic morphological alterations in the mitochondria of adrenocortical cells. In the absence of treatment, the mt compartment appeared as a highly interconnected tubular network with a filamentous appearance. However, after exposure to the drug the compartment exhibited a more punctiform pattern, consistent with mt fragmentation (Fig. 7).

\section{Discussion}

Even though combination of mitotane and cisplatin-based chemotherapy has been recently shown to clinically improve the overall survival in advanced ACC (Fassnacht et al. 2012), mitotane remains the single most active pharmacological option for the management of ACC, as recognized in recent recommendations (Berruti 2012). However, its mechanism of action still remains unclear. In this study, we addressed the question on the mt effects of mitotane on two different human adrenocortical cell lines derived from human ACC aiming at identifying potential molecular targets of the drug. Attempts to perform similar experiments on primary human ACC cells have been so far unsuccessful.

We found that at optimal therapeutic concentrations (50 $\mu \mathrm{M}$, i.e. $14-20 \mathrm{mg} / \mathrm{l})$, mitotane drastically altered $\mathrm{mt}$ function in both steroid-secreting and non-secreting adrenocortical cell lines derived for human ACC. Mitotane inhibited steroid hormone production and secretion, which was accompanied by a reduction in steady-state mRNA levels of genes encoding mt proteins involved in steroidogenesis pathways. More importantly, we demonstrated for the first time that exposure to $50 \mu \mathrm{M}$ mitotane significantly impairs the $\mathrm{mt}$ respiratory chain. Mitotane exposure also stimulated $\mathrm{mt}$ biogenesis and altered $\mathrm{mt}$ morphology in adrenocortical cells.

It is well established that the in vivo anti-proliferative efficacy of mitotane depends on its circulating plasma level (Baudin et al. 2001). However, its pharmacokinetic profile with an unmet need for improved bioavailability

Published by Bioscientifica Ltd. 


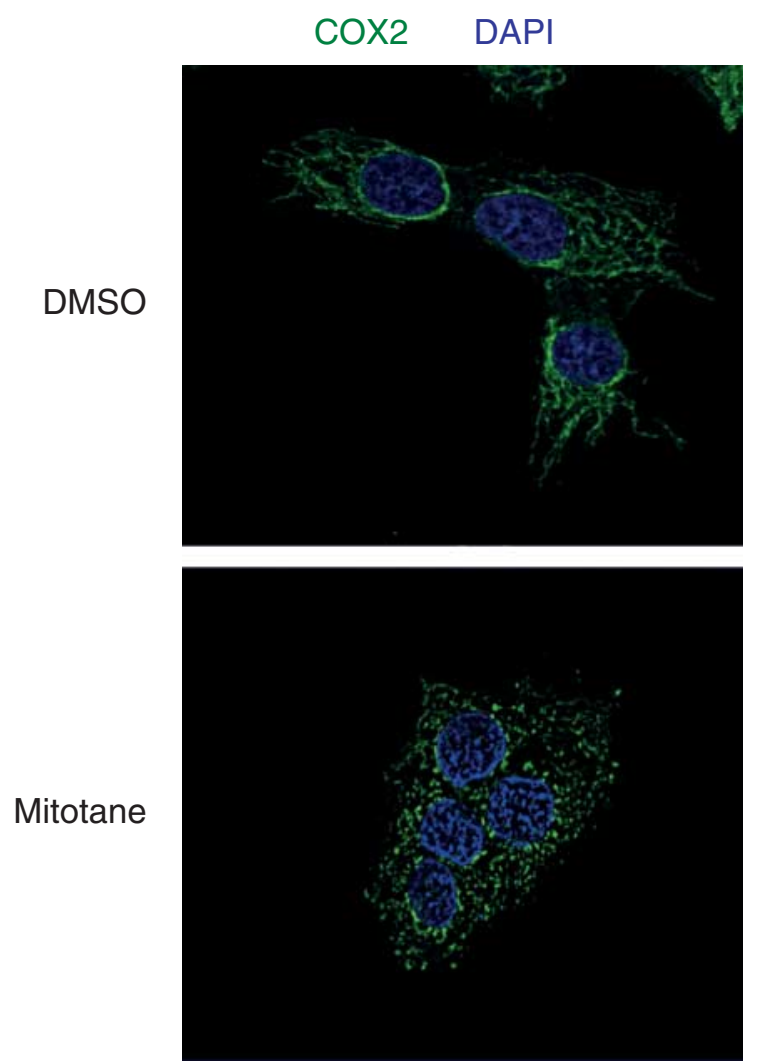

\section{Figure 7}

Morphological changes in the mitochondrial compartment network of H295R cells treated with $50 \mu \mathrm{M}$ mitotane for $48 \mathrm{~h}$. Cells were fixed and immunostained with anti-COX2 antibody (green) and counterstained with DAPI (blue). Under mitotane exposure, the filamentous morphology of the mitochondrial compartment observed in vehicle-treated cells (DMSO) displayed a punctiform pattern, indicative of mitochondrial fragmentation.

and its metabolic conversion constitute potential limitations (Schteingart 2007). It has been suggested that the metabolic transformation of $o, p^{\prime}$-DDD is carried out in the adrenal mitochondria, the first enzymatic step being catalyzed by an unknown P450 cytochrome-mediated hydroxylase leading to an adrenolytic effect (Martz \& Straw 1977, Cai et al. 1995). In accordance with previous studies, we confirmed that mitotane inhibits steroidogenesis reducing cortisol and 17-OH-progesterone secretions by $70 \%$ (Schteingart et al. 1993, Stigliano et al . 2008). Mitotane exposure also decreased mRNA levels of $S T A R$, the cholesterol carrier into the mitochondria, as well as CYP11A, CYP11B1, and CYP11B2, three $\mathrm{mt}$ enzymes involved in cortisol and aldosterone biosynthesis respectively. However, the degree and extent of mitotaneinduced repression of genes involved in steroidogenesis seem to vary greatly between studies (Asp et al. 2012, Lin et al. 2012, Zsippai et al. 2012), supporting mitochondria as a main target of the drug's action.
The mitotane transformation into active acylchlorine metabolites that takes place in the mitochondria of adrenal gland is believed to be responsible for cell toxicity and may explain the selective adrenolytic effect of the drug (Cai et al. 1995, Lindhe et al. 2002). This hypothesis awaits further confirmation at the clinical level (Hermsen et al. 2011). At variance with the hepatic microsomal transformation of mitotane by CYP3A4 (van Erp et al. 2011, Kroiss et al. 2011), which is likely responsible for the pharmacokinetic interaction whereby mitotane reduces plasma levels of sunitinib (Fassnacht et al. 2012, Kroiss et al. 2012), it has been suggested that CYPc11 or CYP11B1 could be involved in tissue-specific and compartment-selective mitotane metabolism (Lund \& Lund 1995, Lindhe et al. 2002). Although CYP11B1 may catalyze the initial hydroxylation step of mitotane (Cai et al. 1995, Lund \& Lund 1995, Lindhe et al. 2002), its direct involvement in mt dysfunction is very unlikely given that SW13 cells, which do no express CYP11B1, were similarly affected by mitotane treatment. In any case, the relationship between the potential hepatic metabolism of mitotane and its adrenal effect remains currently unknown. For instance, it remains to be established whether intra-mt transformation of mitotane into $o, p^{\prime}$-DDA and $o, p^{\prime}$-DDE compounds has deleterious consequences on OXPHOS. However, preliminary results from our laboratory reveal the presence of active mitotane uptake into H295R cells, suggesting that intracellular accumulation of mitotane and/or one of its metabolites may account for its cytotoxic effects.

Given that most enzymatic steps of steroid hormone biosynthesis take place in the mitochondria and that mitotane inhibits steroidogenesis, we examined whether mitotane impedes $\mathrm{mt}$ respiratory chain function. Interestingly, in both H295R and SW13 cells, OXPHOS analyses indicated that mitotane induced a significant and selective decrease in the maximum velocity of COX activity, whereas complex II and III activities were unaltered. Mitotane has both direct and indirect inhibitory effects on COX: direct inhibition of the enzymatic activity was revealed in our experiments on cell homogenate incubation with $o, p^{\prime}$-DDD but the drug also inhibited expression of the enzyme at both the mRNA and protein levels. Inhibition of gene expression was observed for both the mtDNA-encoded COX2 and the nuclear DNA-encoded COX4 subunits. Immunoblotting provided additional support for a reduction in steady-state COX protein expression. Concomitantly, normal activity and expression of respiratory chain complexes II and III or of citrate synthase, a Krebs cycle enzyme, suggest that mitotane caused selective enzymatic disruption rather than global $\mathrm{mt}$ damage, as initially proposed (Kaminsky et al. 1962).

Published by Bioscientifica Ltd 
Herein, we confirm the adrenolytic effect of mitotane by showing that mitotane exposure leads to a time- and concentration-dependent reduction of adrenocortical cell numbers. Interestingly, this was accompanied by enhanced $\mathrm{mt}$ biogenesis, as demonstrated by increased mtDNA content and PGC1 $\alpha$ expression, reminiscent of a cellular compensation mechanism in response to the respiratory chain defect. This adaptive pathway, combining increased mt mass, increased mtDNA copy level and impaired OXPHOS, which has already been reported in $\mathrm{mt}$ myopathies caused by mtDNA mutations (Srivastava et al. 2009). However, no mtDNA mutations or deletions were found by sequencing mtDNA from mitotane-treated cells. Of particular interest, mitotane exposure also triggered morphologic fragmentation of the mt network, which could be related to disequilibrium between $\mathrm{mt}$ fission and fusion (Chen \& Chan 2010). It is well established that the integrity of $m$ t outer and inner membranes is required for respiratory chain activity (Liesa et al. 2009, Chen et al. 2010) and presumably steroidogenesis (Duarte et al. 2012). It is not known, however, whether $\mathrm{mt}$ fragmentation has a direct relationship with or a causal role in genotoxic stress and apoptosis.

In summary, our results show that mitotane alters mt respiratory chain activity in human adrenocortical cells, notably by inducing a COX defect. Further studies are needed to examine whether and how such mitotaneinduced $\mathrm{mt}$ dysfunction translates into adrenolytic and antitumor effects on human ACC (Costa et al. 2011).

\section{Supplementary data}

This is linked to the online version of the paper at http://dx.doi.org/10.1530/ ERC-12-0368.

\section{Declaration of interest}

All authors have no disclosure except $\mathrm{Dr}$ Rita Chadarevian who is an employee of HRA Pharma.

\section{Funding}

This work was supported by the Institut National de la Santé et de la Recherche Médicale (INSERM), Faculté de Médecine Paris-Sud, and a grant from HRA Pharma Laboratories. S H was a recipient of a fellowship from the French Endocrine Society (Société Française d'Endocrinologie (SFE)).

\section{Author contribution statement}

$\mathrm{S} \mathrm{H}, \mathrm{A} S, \mathrm{E} \mathrm{B}$, and $\mathrm{M} \mathrm{L}$ designed the study; $\mathrm{S} \mathrm{H}, \mathrm{A} S, \mathrm{~A} L, S \mathrm{~T}$, and $\mathrm{M} \mathrm{L}$ performed the experiments and analyzed the results; $A, A P, H R, R C, S B$, and $J Y$ helped interpret the data and participated in discussions; and $S \mathrm{H}, \mathrm{EB}$, and $\mathrm{M} \mathrm{L}$ wrote the paper; all the authors have read, revised, and approved the manuscript.

http://erc.endocrinology-journals.org DOI: $10.1530 /$ ERC-12-0368
(C) 2013 Society for Endocrinology Printed in Great Britain

\section{Acknowledgements}

The authors would like to thank C Clémenson (Institut Gustave Roussy, Villejuif, France) for providing cell lines and Dr Say Viengchareun for his help in preparing the figures.

\section{References}

Agier V, Oliviero P, Laine J, L'Hermitte-Stead C, Girard S, Fillaut S, Jardel C, Bouillaud F, Bulteau AL \& Lombes A 2012 Defective mitochondrial fusion, altered respiratory function, and distorted cristae structure in skin fibroblasts with heterozygous OPA1 mutations. Biochimica et Biophysica Acta 1822 1570-1580. (doi:10.1016/j.bbadis.2012.07.002)

Asp V, Ulleras E, Lindstrom V, Bergstrom U, Oskarsson A \& Brandt I 2012 Biphasic hormonal responses to the adrenocorticolytic DDT metabolite 3-methylsulfonyl-DDE in human cells. Toxicology and Applied Pharmacology 242 281-289. (doi:10.1016/j.taap.2009.10.018)

Assie G, Antoni G, Tissier F, Caillou B, Abiven G, Gicquel C, Leboulleux S, Travagli JP, Dromain C, Bertagna X et al. 2007 Prognostic parameters of metastatic adrenocortical carcinoma. Journal of Clinical Endocrinology and Metabolism 92 148-154. (doi:10.1210/jc.2006-0706)

Baudin E, Pellegriti G, Bonnay M, Penfornis A, Laplanche A, Vassal G \& Schlumberger M 2001 Impact of monitoring plasma 1,1-dichlorodiphenildichloroethane $\left(o, p^{\prime} \mathrm{DDD}\right)$ levels on the treatment of patients with adrenocortical carcinoma. Cancer 92 1385-1392. (doi:10.1002/ 1097-0142(20010915)92:6<1385::AID-CNCR1461>3.0.CO;2-2)

Baudin E, Leboulleux S, Al Ghuzlan A, Chougnet C, Young J, Deandreis D, Dumont F, Dechamps F, Caramella C, Chanson P et al. 2011 Therapeutic management of advanced adrenocortical carcinoma: what do we know in 2011? Hormones \& Cancer 2 363-371. (doi:10.1007/s12672-011-0094-2)

Bergenstal DM \& Dao TL 1953 Management of Addison's disease in adrenalectomized patients. Bulletin of the New York Academy of Medicine 29 295-306.

Berruti A 2012 Adrenal cancer: ESMO Clinical Practice Guidelines for diagnosis, treatment and follow-up. Annals of Oncology 23 (supplement 7) 131-138.

Cai W, Benitez R, Counsell RE, Djanegara T, Schteingart DE, Sinsheimer JE \& Wotring LL 1995 Bovine adrenal cortex transformations of mitotane [1-(2-chlorophenyl)-1-(4-chlorophenyl)-2,2-dichloroethane; $o, p^{\prime}$-DDD] and its p, p'- and m, p'-isomers. Biochemical Pharmacology 49 1483-1489. (doi:10.1016/0006-2952(95)00028-X)

Cai W, Counsell RE, Schteingart DE, Sinsheimer JE, Vaz AD \& Wotring LL 1997 Adrenal proteins bound by a reactive intermediate of mitotane. Cancer Chemotherapy and Pharmacology 39 537-540. (doi:10.1007/ s002800050610)

Chen H \& Chan DC 2010 Physiological functions of mitochondrial fusion. Annals of the New York Academy of Sciences 1201 21-25. (doi:10.1111/ j.1749-6632.2010.05615.x)

Chen H, Vermulst M, Wang YE, Chomyn A, Prolla TA, McCaffery JM \& Chan DC 2010 Mitochondrial fusion is required for mtDNA stability in skeletal muscle and tolerance of mtDNA mutations. Cell 141 280-289. (doi:10.1016/j.cell.2010.02.026)

Chretien D, Benit P, Chol M, Lebon S, Rotig A, Munnich A \& Rustin P 2003 Assay of mitochondrial respiratory chain complex I in human lymphocytes and cultured skin fibroblasts. Biochemical and Biophysical Research Communications 301 222-224. (doi:10.1016/S0006291X(02)03016-4)

Costa R, Wesolowski R \& Raghavan D 2011 Chemotherapy for advanced adrenal cancer: improvement from a molecular approach? BJU International 108 1546-1554. (doi:10.1111/j.1464-410X.2011.10464.x)

Duarte A, Poderoso C, Cooke M, Soria G, Maciel FC, Gottifredi V \& Podesta EJ 2012 Mitochondrial fusion is essential for steroid biosynthesis. PLoS ONE 7 e45829. (doi:10.1371/journal.pone.0045829)

Published by Bioscientifica Ltd. 
van Erp NP, Guchelaar HJ, Ploeger BA, Romijn JA, Hartigh J \& Gelderblom H 2011 Mitotane has a strong and a durable inducing effect on CYP3A4 activity. European Journal of Endocrinology 164 621-626. (doi:10.1530/EJE-10-0956)

Fassnacht M \& Allolio B 2009 Clinical management of adrenocortical carcinoma. Best Practice \& Research. Clinical Endocrinology \& Metabolism 23 273-289. (doi:10.1016/j.beem.2008.10.008)

Fassnacht M, Terzolo M, Allolio B, Baudin E, Haak H, Berruti A, Welin S, Schade-Brittinger C, Lacroix A, Jarzab B et al. 2012 Combination chemotherapy in advanced adrenocortical carcinoma. New England Journal of Medicine 366 2189-2197. (doi:10.1056/NEJMoa1200966)

Fedeles BI, Zhu AY, Young KS, Hillier SM, Proffitt KD, Essigmann JM \& Croy RG 2011 Chemical genetics analysis of an aniline mustard anticancer agent reveals complex I of the electron transport chain as a target. Journal of Biological Chemistry 286 33910-33920. (doi:10.1074/jbc. M111.278390)

Haak HR, Hermans J, van de Velde CJ, Lentjes EG, Goslings BM, Fleuren GJ \& Krans HM 1994 Optimal treatment of adrenocortical carcinoma with mitotane: results in a consecutive series of 96 patients. British Journal of Cancer 69 947-951. (doi:10.1038/bjc.1994.183)

Hermsen IG, Fassnacht M, Terzolo M, Houterman S, den Hartigh J, Leboulleux S, Daffara F, Berruti A, Chadarevian R, Schlumberger M et al. 2011 Plasma concentrations of o, $\mathrm{p}^{\prime} \mathrm{DDD}, \mathrm{o}, \mathrm{p}^{\prime} \mathrm{DDA}$, and o, $\mathrm{p}^{\prime} \mathrm{DDE}$ as predictors of tumor response to mitotane in adrenocortical carcinoma: results of a retrospective ENS@T multicenter study. Journal of Clinical Endocrinology and Metabolism 96 1844-1851. (doi:10.1210/jc.2010-2676)

Icard P, Goudet P, Charpenay C, Andreassian B, Carnaille B, Chapuis Y, Cougard P, Henry JF \& Proye C 2001 Adrenocortical carcinomas: surgical trends and results of a 253-patient series from the French Association of Endocrine Surgeons Study Group. World Journal of Surgery 25 891-897. (doi:10.1007/s00268-001-0047-y)

Kaminsky N, Luse S \& Hartroft P 1962 Ultrastructure of adrenal cortex of the dog during treatment with DDD. Journal of the National Cancer Institute 29 127-159.

Kroiss M, Quinkler M, Lutz WK, Allolio B \& Fassnacht M 2011 Drug interactions with mitotane by induction of CYP3A4 metabolism in the clinical management of adrenocortical carcinoma. Clinical Endocrinology 75 585-591. (doi:10.1111/j.1365-2265.2011.04214.x)

Kroiss M, Quinkler M, Johanssen S, van Erp NP, Lankheet N, Pollinger A, Laubner K, Strasburger CJ, Hahner S, Muller HH et al. 2012 Sunitinib in refractory adrenocortical carcinoma: a phase II, single-arm, open-label trial. Journal of Clinical Endocrinology and Metabolism 97 3495-3503. (doi:10.1210/jc.2012-1419)

Liesa M, Palacin M \& Zorzano A 2009 Mitochondrial dynamics in mammalian health and disease. Physiological Reviews 89 799-845. (doi:10.1152/physrev.00030.2008)

Lin CW, Chang YH \& Pu HF 2012 Mitotane exhibits dual effects on steroidogenic enzymes gene transcription under basal and cAMPstimulating microenvironments in NCI-H295 cells. Toxicology 298 14-23. (doi:10.1016/j.tox.2012.04.007)

Lindhe O, Skogseid B \& Brandt I 2002 Cytochrome P450-catalyzed binding of 3-methylsulfonyl-DDE and o,p'-DDD in human adrenal zona fasciculata/reticularis. Journal of Clinical Endocrinology and Metabolism 87 1319-1326. (doi:10.1210/jc.87.3.1319)

Lughezzani G, Sun M, Perrotte P, Jeldres C, Alasker A, Isbarn H, Budaus L, Shariat SF, Guazzoni G, Montorsi F et al. 2010 The European Network for the Study of Adrenal Tumors staging system is prognostically superior to the international union against cancer-staging system: a North American validation. European Journal of Cancer 46 713-719. (doi:10.1016/j.ejca.2009.12.007)
Lund BO \& Lund J 1995 Novel involvement of a mitochondrial steroid hydroxylase (P450c11) in xenobiotic metabolism. Journal of Biological Chemistry 270 20895-20897. (doi:10.1074/jbc.270.36.20895)

Malandrino P, Al Ghuzlan A, Castaing M, Young J, Caillou B, Travagli JP, Elias D, de Baere T, Dromain C, Paci A et al. 2010 Prognostic markers of survival after combined mitotane- and platinum-based chemotherapy in metastatic adrenocortical carcinoma. Endocrine-Related Cancer 17 797-807. (doi:10.1677/ERC-09-0341)

Martinerie L, Viengchareun S, Meduri G, Kim HS, Luther JM \& Lombès M 2011 Aldosterone postnatally, but not at birth, is required for optimal induction of renal mineralocorticoid receptor expression and sodium reabsorption. Endocrinology 152 2483-2491. (doi:10.1210/en.2010-1460)

Martz F \& Straw JA 1977 The in vitro metabolism of 1-(o-chlorophenyl)-1(p-chlorophenyl)-2,2-dichloroethane (o,p'-DDD) by dog adrenal mitochondria and metabolite covalent binding to mitochondrial macromolecules: a possible mechanism for the adrenocorticolytic effect. Drug Metabolism and Disposition 5 482-486.

Nijtmans LG, Artal SM, Grivell LA \& Coates PJ 2002a The mitochondrial PHB complex: roles in mitochondrial respiratory complex assembly, ageing and degenerative disease. Cellular and Molecular Life Sciences 59 143-155. (doi:10.1007/s00018-002-8411-0)

Nijtmans LG, Henderson NS \& Holt IJ $2002 b$ Blue native electrophoresis to study mitochondrial and other protein complexes. Methods $\mathbf{2 6}$ 327-334. (doi:10.1016/S1046-2023(02)00038-5)

Rustin P, Chretien D, Bourgeron T, Gerard B, Rotig A, Saudubray JM \& Munnich A 1994 Biochemical and molecular investigations in respiratory chain deficiencies. Clinica Chimica Acta 228 35-51. (doi:10.1016/0009-8981(94)90055-8)

Scatena R 2012 Mitochondria and drugs. Advances in Experimental Medicine and Biology 942 329-346. (doi:10.1007/978-94-007-2869-1_15)

Schteingart DE 2007 Adjuvant mitotane therapy of adrenal cancer - use and controversy. New England Journal of Medicine 356 2415-2418. (doi:10.1056/NEJMe078087)

Schteingart DE, Sinsheimer JE, Counsell RE, Abrams GD, McClellan N, Djanegara T, Hines J, Ruangwises N, Benitez R \& Wotring LL 1993 Comparison of the adrenalytic activity of mitotane and a methylated homolog on normal adrenal cortex and adrenal cortical carcinoma. Cancer Chemotherapy and Pharmacology 31 459-466. (doi:10.1007/ BF00685036)

Srivastava S, Diaz F, Iommarini L, Aure K, Lombes A \& Moraes CT 2009 PGC- $1 \alpha / \beta$ induced expression partially compensates for respiratory chain defects in cells from patients with mitochondrial disorders. Human Molecular Genetics 18 1805-1812. (doi:10.1093/hmg/ddp093)

Stigliano A, Cerquetti L, Borro M, Gentile G, Bucci B, Misiti S, Piergrossi P, Brunetti E, Simmaco M \& Toscano V 2008 Modulation of proteomic profile in H295R adrenocortical cell line induced by mitotane. Endocrine-Related Cancer 15 1-10. (doi:10.1677/ERC-07-0003)

Viengchareun S, Caron M, Auclair M, Kim MJ, Frachon P, Capeau J, Lombès M \& Lombes A 2007 Mitochondrial toxicity of indinavir, stavudine and zidovudine involves multiple cellular targets in white and brown adipocytes. Antiviral Therapy 12 919-929.

Wangberg B, Khorram-Manesh A, Jansson S, Nilsson B, Nilsson O, Jakobsson CE, Lindstedt S, Oden A \& Ahlman H 2010 The long-term survival in adrenocortical carcinoma with active surgical management and use of monitored mitotane. Endocrine-Related Cancer 17 265-272. (doi:10.1677/ERC-09-0190)

Zsippai A, Szabo DR, Tombol Z, Szabo PM, Eder K, Pallinger E, Gaillard RC, Patocs A, Toth S, Falus A et al. 2012 Effects of mitotane on gene expression in the adrenocortical cell line NCI-H295R: a microarray study. Pharmacogenomics 13 1351-1361. (doi:10.2217/pgs.12.116)

Received in final form 19 March 2013

Accepted 3 April 2013

Made available online as an Accepted Preprint

5 April 2013 http://erc.endocrinology-journals.org

DOI: $10.1530 /$ ERC-12-0368
(C) 2013 Society for Endocrinology Printed in Great Britain
Published by Bioscientifica Ltd 